\title{
ERYTHEMA INDURATUM OF BAZIN AND RENAL TUBERCULOSIS: REPORT OF AN ASSOCIATION
}

\author{
Elizabeth De Francesco DAHER(1,2), Geraldo Bezerra da SILVA JÚNIOR(1), Hugo César Furtado PINHEIRO(1), Tatiane Roseno de OLIVEIRA(1), \\ Maria do Livramento Leitão VILAR(1) \& Karlla Jordão de ALCÂNTARA(1)
}

\begin{abstract}
SUMMARY
Erythema induratum of Bazin is a disease that usually affects women, in whom erythematous subcutaneous nodules and plaques appear on the posterior part of the lower extremities, some of which ulcerate. In many countries, tuberculosis is still the main etiologic factor. We report a case of a 40-year-old woman who presented a course of protracted and recurrent episodes over five years of cutaneous lesions on her legs. These tend to involute, but new crops appear at irregular intervals. It was painful, erythematousviolaceous nodules, some of which drained a reddish secretion. The histopathologic features of the lesions demonstrated inflammatory infiltration, with predominance of neutrophils in dermis and hypodermis, necrotizing vasculitis in the arterioles and septal fibrosis. There was no granuloma. The Ziehl-Neelsen stain did not revealed acid-fast bacilli, and the culture of biopsy specimen was negative. The tuberculin skin test was strongly positive $(17 \mathrm{~mm})$. The chest X-ray was normal. Few months later she presented adynamia and urinary complaints, such as polacyuria and dysuria. It has been done an urynalysis, which demonstrated acid pH urine, sterile pyuria and microscopic hematuria. It was then raised the diagnostic hypothesis of renal tuberculosis. The urine culture for M. tuberculosis was positive in two out of ten samples. The treatment was instituted with rifampin, isoniazid and pyrazinamide, with complete regression. This case illustrates a clear association between erythema induratum and renal tuberculosis, demonstrated by the remission of the cutaneous lesions after the treatment of the renal tuberculosis.
\end{abstract}

KEYWORDS: Erythema induratum of Bazin; Renal tuberculosis; Cutaneous tuberculosis; Vasculitis.

\section{INTRODUCTION}

Erythema induratum of Bazin (EIB) is a chronic nodular eruption that usually occurs on the legs of teenage and middle-aged women ${ }^{5,15,20}$. It was first described by Bazin in 1861, and French dermatologists linked this condition to tuberculosis in $1900^{5}$. The Mycobacterium tuberculosis has been hardly detected in the cutaneous lesions, so that this association has been refuted for a long time ${ }^{5,14,22}$. Many recent studies have found genetic material of $M$. tuberculosis by polymerase chain reaction (PCR) in the samples of cutaneous lesions, suggesting the tuberculous etiology of $\mathrm{EIB}^{2,6,11,12,24,26,29}$.

The disease is characterized by a recurrent pattern, with painful, deep-seated, subcutaneous induration, which gradually extends to the skin surface forming bluish-red nodules or plaques which often ulcerate ${ }^{12}$. The most frequent sites in which the lesions occur are the shins and calves of the lower legs, but they can also occur on the feet, thighs, arms and face ${ }^{12}$. The presentation is usually bilateral and can spontaneously heal, with atrophic hyperpigmented scars ${ }^{18}$.

The histopathologic picture of EIB is characterized by a granulomatous, tuberculoid infiltrate, vascular changes, and areas of caseation necrosis ${ }^{5}$. There is granulomatous infiltration of the subcutis, necrotizing vasculitis with mural thickening of subcutaneous arteries and veins, and perivascular cuffing ${ }^{18,20}$. Areas of fat necrosis are prominent, and foreign-body giant cells and granulomas can be found ${ }^{18}$. Caseation is rare in most reports, and acid-fast bacilli are usually absent. SCHNEIDER \& JORDAAN ${ }^{25}$ studied a group of patients with EIB and divided them into two major histopathologic groups: one presented septolobular panniculitis in close association with a single muscular artery or small vessel with primary neutrophilic vasculitis, while the other one showed diffuse septolobular panniculitis with primary neutrophilic vasculitis of either large or smaller vessels. It was found in both groups varying combinations and degrees of acute and chronic inflammation, coagulative and caseation-like necrosis, and granulomatous inflammation, demonstrating the histopathologic heterogeneous spectrum that can be found in EIB.

The EIB is believed to be an example of tuberculid, which comprises a group of eruptions that arise in response to an internal focus of tuberculosis and is regarded as a hypersensitivity reaction to $M$. tuberculosi ${ }^{5}$. Some authors have found pulmonary tuberculosis in patients with $\mathrm{EIB}^{5,12}$. Other latent foci of internal tuberculosis can be detected in these patients, so an association between renal tuberculosis

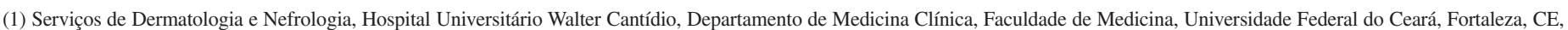
Brasil.

(2) Serviço de Nefrologia, Hospital Geral de Fortaleza, Secretaria de Saúde do Estado do Ceará, Fortaleza, CE, Brasil.

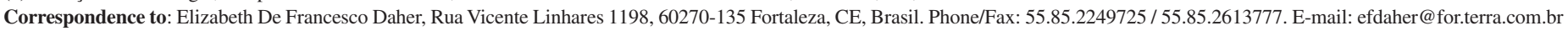




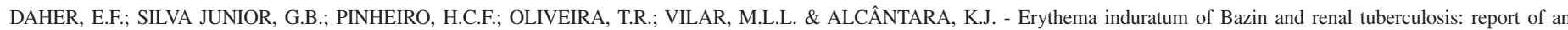
association. Rev. Inst. Med. trop. S. Paulo, 46(5):295-298, 2004.

and EIB had been described one time before by FERNANDEZ del MORAL et al. $^{8}$.

After the informed consent of the patient, we report a case of a woman in whom a renal tuberculosis was diagnosed after a long period presenting symptoms of EIB.

\section{CASE REPORT}

A 40-year-old woman from the countryside of Ceará, northeast of Brazil, had complaints of cutaneous lesions on her legs for five years. She had painful, erythemato-violaceous nodules, some of them ulcerated and draining a reddish secretion (Fig. 1). The lesions used to heal spontaneously and reappeared every month. In her past history, the only remarkable disease was syphilis, ten years ago, and was successfully treated with antibiotics. It has been done biopsy of one of the cutaneous lesions, which demonstrated inflammatory infiltration, with predominance of neutrophils in dermis and hypodermis, vasculitis in the arterioles and septal fibrosis. There was no granuloma. The ZiehlNeelsen stained sections did not revealed acid-fast bacilli, and the culture of biopsy specimen was negative. The tuberculin skin test (PPD) was positive, demonstrating a reaction of $17 \mathrm{~mm}$. The chest X-ray was normal.

Few months later she presented adynamia and urinary complaints, such as polacyuria and dysuria. She had no fever or other symptoms.
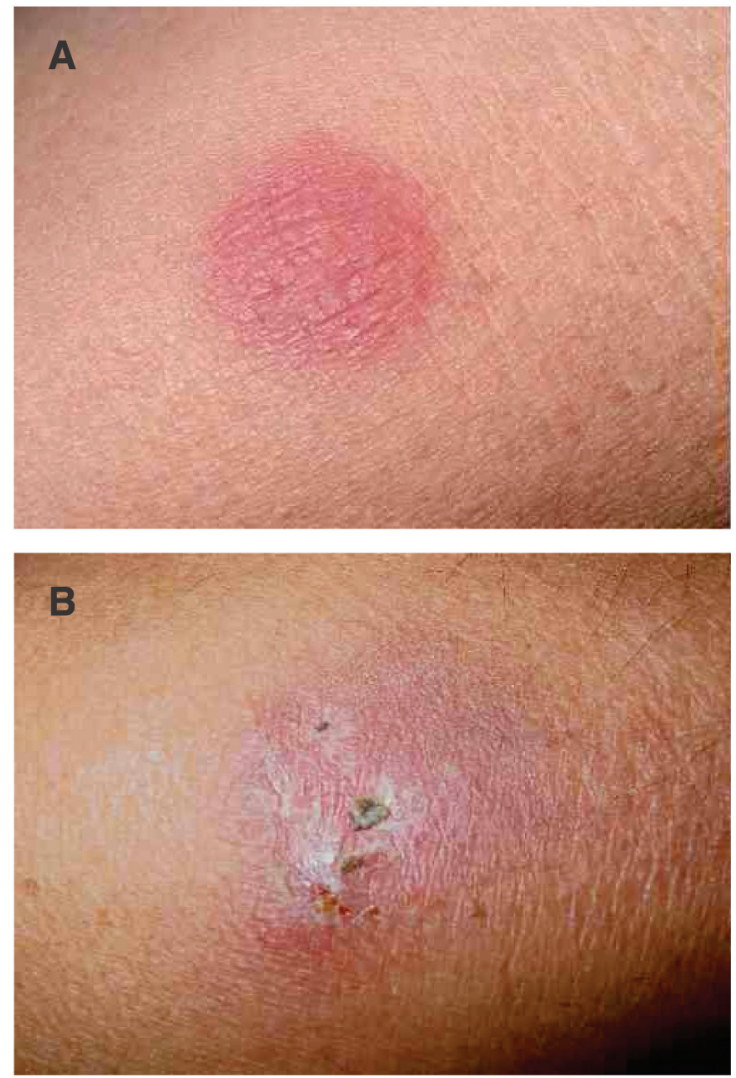

Fig. 1 - Erythema induratum of Bazin (nodular vasculitis). Erythematous nodules on posterior aspect of the lower legs and some of them ulcerated. A: non-ulcerated. B: ulcerated and crusted.
The urynalysis showed an acid urine $(\mathrm{pH}=5.5)$, sterile pyuria and microscopic hematuria (6 erythrocytes per high power field). The quantification of pyuria and hematuria through the method of Addis demonstrated the presence of more than 1,600,000 erythrocytes (reference value: $<500,000$ ) and pyocites (reference value: $<1,000,000)$. It was then suspected of renal tuberculosis, which is characterized by a latent course and can manifest only inespecific urinary symptoms and hematuria ${ }^{29}$. The intravenous urography showed kidneys with normal aspect. It was performed urine culture for $M$. tuberculosis that was negative in eight consecutive samples, being positive in the two last ones.

The treatment was instituted with antituberculous drugs (rifampin $600 \mathrm{mg} /$ day, isoniazid - $200 \mathrm{mg}$ /day and pyrazinamide - $2 \mathrm{~g} /$ day for two months, and rifampin plus isoniazid for four months), after which she presented a great improvement. Two months after the beginning of the treatment, the cutaneous lesions and the urinary symptoms had disappeared. During her follow-up (three months after the end of the treatment) it was recorded no relapse of the skin lesions or signals of renal disease.

\section{DISCUSSION}

Erythema induratum of Bazin (EIB) is characterized by chronic, tender, erythemato-violaceous, indurated and often ulcerative subcutaneous nodules on the lower extremities of women with tuberculin hypersensitivity ${ }^{5,24}$. All this was seen in our patient, which presented these classical skin lesions, with a recurrent pattern since five years ago.

The diagnosis of EIB can be made through suggestive clinical and histopathological features, positive epidemiology for tuberculosis, positive PPD test and response to the treatment with tuberculostatics ${ }^{21}$. In our case, the diagnosis was possible analyzing the clinical pattern of the cutaneous lesions, the histopathological features and the strongly positive PPD test, all suggestive of erythema induratum. The appearance of urinary symptoms raised the suspicion of associated renal tuberculosis, which could be the focus responsible for the development of cutaneous involvement. KRAEMER et al. ${ }^{13}$ reported a case of a young woman who developed skin lesions on her legs similar to those seen in this patient, with no evidence of renal tuberculous infection. LAFUENTEURREZ et al. ${ }^{15}$ described a similar case. In both, the tuberculin skin test was strongly positive, suggesting a strong correlation of the erythema induratum with tuberculosis.

It is still not known the exact pathogenesis of EIB. It is not clear if it is a true tuberculosis with viable organisms in the lesions, coming through hematogenous spread to the skin from a distant latent focus elsewhere in the body ${ }^{12,24}$. It is believed that EIB represent a hypersensitivity reaction, type III or IV (tuberculid), to $M$. tuberculosis antigens in patients with a high degree of tuberculin hypersensitivity ${ }^{5,24}$. The histopathologic features are heterogeneous and include necrotizing vasculitis, granulomatous infiltration, with caseation necrosis ${ }^{5,17,20,28}$. The detection of the bacilli through PCR technique strongly suggests the tuberculous etiology of this disease $e^{2,6,11,12,24,26,29}$. The PCR has a sensitivity of $98 \%$ and specificity of $100 \%$, being an excellent method for the diagnosis of EIB, but has the disadvantage of being expensive ${ }^{21}$. The EIB is also called nodular vasculitis ${ }^{18}$. The deposition of immune complex in the vessel walls has been described as responsible for nodular vasculitis, but it has not been found immunedeposits or complement in the skin 
lesions of EIB. The term EIB should be reserved for those cases of nodular vasculitis in which components of tubercle bacilli are causative ${ }^{14}$.

The association between EIB and focus of tuberculosis, in the lungs, pleura, pericardium, peritoneum, lymph nodes and endometrium, has been described in the medical literature ${ }^{5,8,9,10,12,16,27}$. It is estimated that, in 25 to $70 \%$ of the patients with EIB, M. tuberculosis can be found in the skin lesions through the PCR. In the remaining patients, the disease is considered to be idiopathic ${ }^{4}$. In most cases, the EIB occurs without demonstrable focus of tuberculous infection, being the tuberculous etiology suggested by a positive $\mathrm{PPD}^{7,19}$. The case presented here shows a clear association between EIB and renal tuberculosis, with the later being diagnosed some years after the beginning of the cutaneous lesions. In the female patient described by FERNANDEZ del MORAL et al. ${ }^{8}$ the renal tuberculosis was diagnosed seven years after the beginning of the symptoms of erythema induratum. In the case presented here the interval between the appearance of urinary symptoms and the skin lesions was five years, demonstrating the latent pattern of the renal tuberculosis. The diagnosis was confirmed, in both cases, through a positive urine culture for M. tuberculosis.

Tuberculosis can cause two forms of renal disease, which are direct infection or secondary amyloidosis ${ }^{23}$. Renal tuberculosis, the third more frequent kind of extrapulmonary tuberculosis ${ }^{1}$, is a common missed genitourinary infection that should be considered in any case of urinary symptoms, like pyuria or hematuria, which do not respond to common antibacterial drugs ${ }^{30}$. This condition is always secondary to a pulmonary infection, though in the majority of cases this primary focus has healed or is quiescent. The bacilli can reach other organs, including the kidneys, via the hematogenous route ${ }^{30}$.

The onset of clinically evident genitourinary tuberculosis is often insidious, with dysuria and gross hematuria being the most common symptoms ${ }^{1}$. The time between the infection and the appearance of symptoms can reach as far as twenty years ${ }^{1}$. Some patients are asymptomatic, being pyuria and/or microscopic hematuria found incidentally. These two abnormalities are present in more than $90 \%$ of cases $^{23}$. Our patient presented no evidence of pulmonary infection and developed urinary symptoms after the appearance of skin lesions suggestive of erythema induratum. These two conditions together strongly suggested the etiology of the cutaneous and renal disease as being tuberculosis.

The diagnosis of renal tuberculosis is difficult, because it is hard to identify the organisms in the urine. BENNANI et al. ${ }^{3}$, studying 109 cases of renal tuberculosis, have found bacilli in the urine of 41 patients $(38 \%)$. This is comprehensible because bacilli are shed into the urine intermittently, resulting in only 30 to $40 \%$ of single urine specimens to be positive in patients with active disease ${ }^{23}$. The urine is classically sterile by routine culture, with concurrent bacteriuria occurring in some cases. The urinary $\mathrm{pH}$ is usually acid, which is an important feature to differentiate from the common urinary infections ${ }^{1}$. The find of dysuria, sterile pyuria, hematuria and characteristic radiological features are highly suggestive of renal tuberculosis, but it has to be confirmed through urine culture, which is the gold standard method for establishing the diagnosis ${ }^{23}$. However, the finding of acid-fast bacilli in the urine with a Ziehl-Neelsen stain or fluorescent dye techniques is not pathognomonic for this disorder, since nonpathogenic mycobacteria may occasionally be present ${ }^{23}$. In the case presented here, $M$. tuberculosis has not been found through acidfast bacilli staining. The diagnosis was confirmed only after ten sequential urine cultures.

Intravenous urography can also be used in the investigation of renal tuberculosis, which can shows characteristic signs, mainly in the ureter or the pielocalycial region ${ }^{3,30}$. It can be seen erosion of the tips of the calyces, blunting of the calyces or overt papillary necrosis, and parenchymal scarring and calcification. In the present case, the radiologic findings did not demonstrate any significant abnormality.

The treatment of both EIB and renal tuberculosis consists in antituberculous drugs (rifampin, isoniazid and pyrazinamide). It led to the resolution of the skin lesions and urinary symptoms of our patient. The favorable response to these drugs can be used to confirm the tuberculous etiology of the EIB. In all the cases reported before the patients presented a great improvement after the administration of antituberculous agents, and there was no evidence of recurrence after the correct treatment $t^{8,12,13,15}$. Relapses occur only when the therapy is inadequate, with the use of only two drugs or short period of antituberculous treatment (less than 9 months) or in the cases with drugresistant bacilli ${ }^{9,22}$. In the case of renal tuberculosis, antituberculous agents are successful in eradicating active infection in almost all patients. Ureteral strictures may progress during treatment due to scarring and subsequent narrowing of the lumen. It is recommended to perform intravenous urography or renal ultrasound every six months for the first two years in patients with ureteral strictures to detect possible urinary tract obstruction ${ }^{23}$.

In summary, this case illustrates a rare form of cutaneous tuberculosis (erythema induratum) associated with renal tuberculosis, a urinary infection commonly missed in the clinical practice. The key points in the diagnosis of EIB are the clinical and histological characteristics of the skin lesions, mainly on the legs, the classical recurrent pattern of presentation, the strongly positive tuberculin skin test, the possible evidence of tuberculosis elsewhere in the body and the good response to the treatment with antituberculous drugs. Renal tuberculosis is hard to diagnose and should always be investigated in a patient with EIB.

\section{RESUMO}

\section{Eritema indurado de Bazin e tuberculose renal: relato de uma associação}

O eritema indurado de Bazin é doença caracterizada por erupções cutâneas que usualmente ocorrem nos membros inferiores de mulheres adolescentes e de meia idade. Relatamos o caso de paciente de 40 anos que apresentava há 5 anos lesões cutâneas em região inferior de ambas as pernas. Tratavam-se de nódulos eritemato-violáceos, dolorosos, alguns dos quais drenavam secreção serossangüínea. $\mathrm{O}$ exame histopatológico da biópsia de pele demonstrou infiltrado inflamatório, com predomínio de neutrófilos na derme e hipoderme, vasculite necrosante em arteríolas e fibrose septal. Não foram identificados granulomas. A coloração de Ziehl-Neelsen não revelou bacilos álcool-ácido resistentes, e a cultura do material biopsiado foi negativa. O PPD foi fortemente reator $(17 \mathrm{~mm})$. $\mathrm{O}$ raio-X de tórax era normal. Alguns meses depois, a paciente evoluiu com adinamia e sintomas urinários, como polaciúria e disúria. O exame de urina mostrou urina ácida, piúria estéril e hematúria. Foi levantada a 


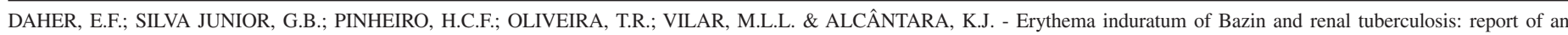
association. Rev. Inst. Med. trop. S. Paulo, 46(5):295-298, 2004.

hipótese de tuberculose renal. A urinocultura foi positiva para $M$. tuberculosis em duas amostras de dez solicitadas. O tratamento foi instituído com rifampicina, isoniazida e pirazinamida, com melhora considerável do quadro. Este caso ilustra uma associação clara entre o eritema indurado e a tuberculose renal, demonstrada através da remissão das lesões cutâneas após o tratamento da tuberculose renal.

\section{REFERENCES}

1. AFIUNE, J.B. - Tuberculose extrapulmonar. In: VERONESI, R. \& FOCACCIA, R., ed. Tratado de Infectologia. 2. ed. São Paulo, Atheneu, 2002. p. 964-969.

2. ARORA, S.K.; KUMAR, B. \& SEHGAL, S. - Development of a polymerase chain reaction dot-blotting system for detecting cutaneous tuberculosis. Brit. J. Derm., 142: 72 $76,2000$.

3. BENNANI, S.; FEKAK, H.; HAFIANI, A. et al. - La tuberculose urogénitale. À propos de 109 cas. Méd. Mal. infect., 29: 19-25, 1999.

4. BOLOGNIA, J.L. \& BRAVERMAN, I.M. - Manifestações cutâneas de doenças internas. In: BRAUNWALD, E.; FAUCI, A.S.; KASPER, D.L. et al., ed. Harrison Medicina interna. 15. ed. Rio de Janeiro, McGraw-Hill, 2002. p. 347-348.

5. CHO, K.H.; LEE, D.Y. \& KIM, C.W. - Erythema induratum of Bazin. Int. J. Derm., 35: 802-808, 1996.

6. DiAZ, C.; CUCURRELL, M.; JEREMIAS, J. et al. - Tuberculosis verrucosa cutis, erythema induratum and PCR. J. Europ. Acad. Derm. Vener., 9 (suppl. 1): S129, 1997.

7. FEIWEL, M. \& MUNRO, D.D. - Diagnosis and treatment of erythema induratum (Bazin). Brit. med. J., 5442: 1109-1111, 1965.

8. FERNANDEZ del MORAL, R.; ERENO, C.; ARRINDA, J.M. \& ALVAREZ DE MON, M. - Erythema induratum of Bazin and active renal tuberculosis. J. Amer. Acad. Derm., 31: 288-290, 1994.

9. FÖRSTRÖM, L. \& HANNUKSELA, M. - Antituberculous treatment of erythema induratum of Bazin. Acta derm.-venereol. (Stockh.), 50: 143-147, 1970.

10. HASSOUN, P.M.; SHEPHERD, K.E.; FLOTTE, T.J. \& KAZEMI, H. - Erythema induratum and active pulmonary tuberculosis. Amer. J. Med., 84: 784-785, 1988.

11. HEINEMANN, C.; KAATZ, M. \& ELSNER, P. - Erythema induratum of Bazin and Poncet's disease: successful treatment with antitubercular drugs. J. Europ. Acad. Derm. Vener., 17: 334-336, 2003.

12. JACINTO, S.S. \& NOGRALES, K.B. - Erythema induratum of Bazin: role of polymerase chain reaction in diagnosis. Int. J. Derm., 42: 380-381, 2003.

13. KRAEMER, C.K.; SILVEIRA, C.M.; RUTHNER, F.G. \& GARCIA, C.R. - Eritema indurado de Bazin. J. bras. Med., 83: 68-69, 2002.

14. KURAMOTO, Y.; AIBA, S. \& TAGAMI, H. - Erythema induratum of Bazin as a type of tuberculid. J. Amer. Acad. Derm., 22: 612-616, 1990.
15. LAFUENTE-URREZ, R.F.; DACHARY-PAGOLA, M.T. \& RUIZ-LAIGLESIA, F. Lesiones nodulares en extremidades inferiores de larga evolución. Eritema indurado de Bazin [Letter]. An. Med. interna (Madrid), 20: 498, 2003.

16. LEBEL, M. \& LASSONDE, M. - Erythema induratum of Bazin. J. Amer. Acad. Derm., 14: 738-742, 1986.

17. MACEIRA, J.M.P.; FUKUYAMA, K.; EPSTEIN, W.L. \& ROWDEN, G. Immunohistochemical demonstration of S-100 protein antigen-containing cells in beryllium-induced, zirconium-induced and sarcoidosis granulomas. Amer. J. clin. Path., 81: 563-568, 1984

18. MacGREGOR, R.R. - Cutaneous tuberculosis. Clin. Derm., 13: 245-255, 1995.

19. MICHELSON, H.E. - Inflammatory nodosa lesions of the lower leg. Arch. Derm. Syph. (Chic.), 66: 327-332, 1952.

20. MURPHY, G.F. \& MIHM-Jr., M.C. - A pele. In: COTRAN, R.S.; KUMAR, V.; ROBBINS S.L. \& SCHOEN, F.J., ed. Robbins Patologia estrutural e funcional. 5. ed. Rio de Janeiro, Guanabara-Koogan, 1996. p. 1058-1093.

21. NASCIMENTO, L.V.; RODRIGUES, A.G.; CARNEIRO, M.B.X. et al. - Tuberculose cutânea no Brasil. An. bras. Derm., 71: 21-24, 1996.

22. RADEMAKER, M.; LOWE, D.G. \& MUNRO, D.D. - Erythema induratum (Bazin's disease). J. Amer. Acad. Derm., 21: 740-745, 1989.

23. ROSE, B.D. - Renal disease in tuberculosis. UpToDate, 2002. In: http:// www.uptodate.com.

24. SCHNEIDER, J.W.; GEIGER, D.H.; ROSSOUW, D.J. et al. - Mycobacterium tuberculosis DNA in erythema induratum of Bazin [Letter]. Lancet, 342: 747-748, 1993.

25. SCHNEIDER, J.W. \& JORDAAN, H.F. - The histopathologic spectrum of erythema induratum of Bazin. Amer. J. Dermatopath., 19: 323-333, 1997.

26. SECKIN, D.; HIZEL, N. \& DEMIRHAN, B. - Erythema induratum of Bazin: identification of mycobacterium tuberculosis DNA by the polymerase chain reaction. J. Europ. Acad. Derm. Vener., 9 (suppl. 1): S193, 1997.

27. SILVA, H.J.; GOONETILLEKE, A.K.E.; SILVA, N.R.; AMARASEKERA, L.R. \& JAYAWICKRAMA, U.S. - Erythema induratum (of Bazin) in a patient with endometrial tuberculosis. Postgrad. med. J., 64: 242-244, 1988.

28. SMOLLE, J. - T-zone histiocytes in granulomatous skin diseases. Dermatologica (Basel), 171: 316-320, 1985.

29. TAN, S.H.; TAN, B.H.; GOH, C.L. et al. - Detection of Mycobacterium tuberculosis DNA using polymerase chain reaction in cutaneous tuberculosis and tuberculids. Int. J. Derm., 38: 122-127, 1999.

30. WILLIAMS, R.D.; COOPER, C.S. \& DONOVAN-Jr., J.F. - Urology. In: WAY, L.W. \& DOHERTY, G.M., ed. Current surgical diagnosis and treatment. 11. ed. New York, McGraw-Hill, 2003. p.1013-1084.

Received: 9 June 2004

Accepted: 27 September 2004 